\title{
Credit Risk Assessment Models of Retail Microfinancing: The Case of a Malaysian National Savings Bank’s Branch
}

\author{
Mazni Asrida Abdullah ${ }^{1}$, Azlina Ahmad ${ }^{2}$, Nor Azam Mat Nayan ${ }^{3}$, Zubir Azhar $^{4}$ \& Abd-Razak Ahmad ${ }^{5}$ \\ ${ }^{1}$ Bank Simpanan Nasional, Alor Setar, Kedah, Malaysia \\ ${ }^{2}$ Maybank Berhad, Georgetown, Penang, Malaysia \\ ${ }^{3}$ Bank Negara Malaysia, Georgetown, Penang, Malaysia \\ ${ }^{4}$ School of Management, Universiti Sains Malaysia, Penang, Malaysia \\ ${ }^{5}$ Faculty of Computer and Mathematical Sciences, Universiti Teknologi MARA, Kedah, Malaysia \\ Correspondence: Zubir Azhar, School of Management, Universiti Sains Malaysia, Penang, Malaysia. E-mail: \\ zubirazhar@usm.my
}

Received: March 16, 2020

Accepted: April 30, 2020

Online Published: June 29, 2020

doi:10.5430/ijfr.v11n3p73

URL: https://doi.org/10.5430/ijfr.v11n3p73

\begin{abstract}
Internal ratings have been used by banks to evaluate the creditworthiness of their borrowers with diverse practices. This research aims to analyse the practice of assessing (or predicting) the credit performance of microfinancing loans of a Malaysian bank and to suggest how the existing performance of credit assessment model can be improved. Logistic regression was used to investigate the predictive ability of information on business operators' management and accounting skills as factors to predict default risk of borrowers. The combination of these information formed the three (3) models that were used in the analysis. The accuracy rate of each model was then measured. A sample of respondents was selected among microfinance borrowers in a national savings bank's branch in Malaysia. A total of 106 questionnaires were used for data analysis. The findings suggest that good credit rating, business experience, business financial and forecasting capability are factors associated with whether SMEs will default or not in their payments. The combination of credit score used currently by the bank and the new information produced by this research increases the bank's ability to predict default.
\end{abstract}

Keywords: credit risk assessment, default prediction, microfinance, retail

\section{Introduction}

Since the 1990s, internal ratings have been used by banks to evaluate the creditworthiness of their borrowers (Treacy \& Carey, 2000). The practice of internal ratings is different between banks as reflected in their different procedures, policies and guidelines. Such a practice represents a basis for loan approval, pricing of loans, loan monitoring and loss provisioning (Grunert, Norden, \& Weber, 2005; Cornée, 2017). The most critical issue facing most banks in granting loans is the capability of borrowers to repay their loans consistently as per agreed terms. A fundamental problem that often arises relates to how banks accurately evaluate credit risk exposure at the transaction and portfolio levels.

Banks that operate their lending business in wealthy countries have regarded credit scoring as an important practice in assessing credit risk for loan applications. Credit scoring uses quantitative financial performance information (that is mainly based on historical data) to predict future performance of loans (Schreiner, 2000; Dimitras, Papadakis, \& Garefalakis, 2017; Doumpos, Lemonakis, Niklis, \& Zopounidis, 2019; see also Abdou \& Pointon, 2011). Apart from financial information, non-financial information is also regarded as important measures in determining banks' credit risk. Financial or quantitative historical data may be less useful if used in isolation to gain a better understanding of borrowers' patterns of payments. Psillaki, Tsolas, and Margaritis (2010) suggested that a default model of various information type could enhance a bank's ability to predict business defaults more efficiently than a model that relies only on the use of financial indicators. Several authors have emphasised the importance of qualitative data by drawing a conclusion that a predictor of business failure that relies solely on financial information has little capability of predicting business failure (Zavgren, 1985; Psillaki et al., 2010; cf. Jayasekera, 2018). 
In view of the above, this paper has two-fold aims, i.e. to analyse the practice of assessing (or predicting) the credit performance of microfinancing loans and to improve the performance of credit assessment based on a credit scoring model used by a Malaysian bank in providing microfinancing loans. We define default as failure to meet the repayment terms of a loan agreement when due. We argue that the use of the scoring system as used currently by the bank in the study may not accurately determine the overall credit risk of borrowers due to incomplete assessment criteria or the absence of information on financial management (representing both managerial and accounting variables in the context of this study) within the reach of business operators. Undeniably, there are many empirical studies that have emphasised the importance of performance measures that used financial ratios in default prediction (see e.g. Ahmad, Azhar, \& Wan-Abu-Bakar, 2010; Dimitras et al., 2017; Doumpos et al., 2019). Albeit with various degrees of success, the predictive ability of non-financial information remains largely unexplored (Psillaki et al., 2010). In this paper, default risk prediction models are developed to measure the predictive ability of the credit score used currently by a bank, as well as the effects of combining the credit score with the information on financial management (which is expected to enhance business operators' skills). Based on the developed models, we pose the following research question:

"Can information on business operators' management and accounting skills improve a bank's ability to predict default?"

The above question should enable this study to identify good model characteristics, or what might be termed as "best practice" in assessing the risk to predict default in repaying loans associated with microfinance. Microfinance, as opposed to conventional financial service in general, is a retail financial service that is offered to individuals or firms associated with relatively small income (Siti-Nabiha, Azhar, Isa, \& Siti-Nazariah, 2018a; Siti-Nabiha, Azhar, \& Ali-Mokhtar, 2018b; Siti-Nazariah, Siti-Nabiha, \& Azhar, 2016).

We investigate whether the current credit assessment using the credit scoring method practiced by a bank in Malaysia can effectively evaluate and predict the default risk of its microfinance service offered to certain groups of customers. We argue that the credit scoring system as practiced by the bank for microfinance applications may not be sufficient to predict the default risk whether the loan repayment will be non-default or default in the future. This is because, although credit score ratings appear to be good at the initial stage of credit assessment, there are cases where borrowers have defaulted payments. In view of the above, this paper aims to achieve the following objectives:

a) To examine whether a model that consist of information on business operators' management and accounting skills leads to a better prediction of default than the current model used by the bank.

b) To determine the predictive ability of the independent variables that consists of information on business operators' management and accounting skills.

The paper evaluates the effectiveness of credit scoring system used by a bank in Malaysia for credit assessment to predict borrowers' ability to honour microfinance loan repayments. It attempts to justify that the use of financial information alone is insufficient to predict default. Instead, it argues that non-financial information should complement the financial information (Siti-Nabiha et al., 2018a; Siti-Nabiha et al., 2018b; Siti-Nazariah et al., 2016), particularly in the credit assessment of microfinancing to predict default. In analysing this credit assessment, the paper has examined microfinance borrowers who have enrolled into its microfinance offerings. The target respondents are borrowers in retail business (Note 1) located within the radius of five (5) km from one of the bank's branches. The microfinance borrowers' business size is the same and is categorised under microenterprise. Microenterprise is defined by Bank Negara Malaysia according to annual sales turnover and number of full-time employees (see Table 1 below).

Table 1. Bank Negara Malaysia's definition of microenterprise

\begin{tabular}{lllr}
\hline Description & $\begin{array}{l}\text { Manufacturing (including } \\
\text { Agro-Based) \& } \\
\text { Manufacturing Related } \\
\text { Services }\end{array}$ & $\begin{array}{l}\text { Primary } \\
\text { Agriculture } \\
\text { Services \& } \begin{array}{r}\text { Sector } \\
\text { (including ICT) }\end{array}\end{array}$ \\
\hline Annual sales & Less than RM250,000 & $\begin{array}{l}\text { Less } \\
\text { RM200,000 }\end{array}$ & than \\
$\begin{array}{l}\text { No. of full-time } \\
\text { employees }\end{array}$ & Less than 5 employees & $\begin{array}{l}\text { Less than } \\
\text { employees }\end{array}$ & 5 \\
\hline
\end{tabular}


According to Bank Negara Malaysia (2004), a microenterprise in manufacturing (including agro-based) and manufacturing related services is an enterprise with full-time employees of less than five (5) or with annual sales turnover of less than RM250,000. Meanwhile, a microenterprise in services is an enterprise with full-time employees of less than five (5) or with annual sales turnover of less than RM200,000.

\section{Literature Review}

Given that the focus of this study concerns the use of financial and non-financial information in predicting the default risk of microfinance borrowers, this section reviews some extant literature. Indeed, a variety of analytical techniques is being used for default prediction in the previous research work. They include statistical methods for example linear, multivariate or quadratic discriminant analysis, logistic and probit regression analysis, models based on contingent claims and asset value coverage of debt obligations, neural networks and operational research methods, such as linear or quadratic programming and data envelopment analysis (Psillaki et al., 2010).

In this study, we use logistic regression to investigate the financial and non-financial factors which are being used to predict the default risk of borrowers. The logistic regression is particularly useful in determining the probability of firms to survive or fail as a function of financial and non-financial performance indicators (Psillaki et al., 2010). In their US-based research on the use of non-financial information in SMEs' risk management practices, Altman and Sabato (2007) had used the logistic regression for default prediction (see also Altman, Sabato, \& Wilson, 2017).

\subsection{Credit Scoring and Financial Information}

The extant literature has long recognised that credit scoring can predict default risk based on the quantitative information generated from particular management information systems. According to Schereiner (2000), such scoring can predict risk based on the performance of previous loans that have similar characteristics with current loans. While the prediction may have influenced organisational decision-making processes, they assert that rating or scoring has been extensively used by financial institutions for loan approval, management reporting, pricing, limit setting and loan loss provisioning.

At the initial stage of a loan application, a bank would require an applicant (i.e. a potential borrower) to provide some information, such as taxes for three (3) consecutive years, current proof of any income (through savings information) and financial statement. As Altman and Sabato (2007) claim, although the bank only considers a snapshot of the applicant's current economic position, it does not consider the ability of the applicant to bring the loan to maturity.

Altman and Sabato (2007) stated that in predicting default, small companies' risk management practices cannot be managed only using "bureau information". Instead, they argue that such practices should be managed through a more extensive financial analysis. This suggests the relevance of financial information used for credit rating purposes is largely acknowledged (Grunert et al., 2005). Financial analysis is essential in determining the financial strength of a company to predict the default. It is commonly accepted that financial factors should be able to capture the main determinants of default especially when the time of the event is approaching (Bottazzi, Da Rin, \& Hellmann, 2009).

Credit rating or credit scoring is described as a "mixture of mathematical models and management intuition" (Krahnen \& Weber, 2001, p. 17). This explains the need for processing officers to evaluate every loan application and recommend whether the loan is good or otherwise based on their intuition and good judgment. Basically, the evaluation ought to consider the overall financial details of borrowers which forms part of the prediction of the default risk.

\subsection{Credit Scoring and Non-financial Information}

Apart from quantitative information, another aspect of credit assessment that needs to be given a fair consideration is non-financial information. Such non-financial information as age of business and size of borrowing firms have been regarded as significant determinants in predicting the default risk (Grunert et al., 2005). A study conducted by Altman and Sabato (2007) reports that the length of business existence is one of the non-financial measures that have been used to predict the default (see also Bottazzi et al., 2009; Altman et al., 2017 and Doumpos et al., 2019). Indeed, there is an increasing interest among banks to use non-financial measures to make lending decisions.

A study conducted by Gunther and Grunin (2000) involving 145 German banks, for example, reports that 70 banks use qualitative, in addition to the quantitative, information to assess credit risk management quality. In the context of their study, such quality measures as education level, experience, marketing analysis, management capability in handling the business have been used in assessing the quality management. While the assessment of the quality management has been popular in the commercial banking industry, it is not uncommon to microfinance industry as well.

There are numerous studies that have looked at microfinance providers' experiences in dealing with loans (see e.g. Norell, 2001; Battilana \& Dorado, 2010; Addae-Korankye, 2014; Aidoo \& Mensah, 2018). Norell's (2001) study, for 
example, indicated that microfinance providers have experienced massive cases of default loans. It reported that such cases are due to several reasons that are non-financial in nature. In explaining the influence of this non-financial information, we highlight the following four (4) main reasons. First, borrowers tend to assess lenders if they are serious about collecting loan payments that are due or outstanding. This is based on their perception that banks are providing microfinance services which are funded by external donors (e.g. the government or overseas sponsors) (Siti-Nabiha et al., 2018b), hence little pressures for banks to pursue effective collection efforts. Second, borrowers' lives are often exposed to unpredictable crises, such as illness or death of family members. Thus, it is not uncommon for borrowers to utilise borrowed funds to resolve their crises. Third, loan amounts that exceed the required cash needs for planned business activities, extra funds may be used for personal consumptions. When the loan needs to be repaid, the borrowers might find it difficult to repay without de-capitalising the business, hence end up utilising the net equity that their businesses generated to fulfil their financial obligations. Finally, if the loans are granted based on favouritism, borrowers may find ways to delay or default loan repayments on purpose. They may even hope banks to write-off their loans rather than to take the borrowers to court or seize their properties.

\subsection{Microfinancing and Loan Assessment}

The collapse of microfinance institutions throughout the world is mainly caused by microfinance loan default (Sama \& Casselman, 2013). Extant literature has long recognised that credit scoring can predict default risk based on the quantitative information generated from particular management information systems. According to Schreiner (2000), such scoring can predict risk based on the performance of previous loans that have similar characteristics with current loans. While the prediction may have influenced organisational decision-making processes, they assert that rating or scoring has been extensively used by financial institutions for management reporting, pricing, limit setting and loan approval and loan loss provisioning.

At the initial stage of a loan application, a bank would require an applicant (i.e. a potential borrower) to provide some information, such as taxes for three (3) consecutive years, current proof of any income (through savings information) and financial statement. As Altman and Sabato (2007) claimed, the bank only considers a snapshot of the applicant's current economic position, it does not consider the ability of the applicant to bring the loan to maturity. They suggested that in predicting default, small companies' risk management practices should be managed through a more extensive financial analysis. This suggests the relevance of financial information used for credit rating purposes is largely acknowledged (Grunert et al., 2005; Ahmad et al., 2010). Financial analysis is essential in determining the financial strength of a company to predict default (Ahmad et al., 2010).

However, apart from quantitative information, another aspect of credit assessment that needs to be given a fair consideration is non-financial information. Such non-financial information as age of business and size of borrowing firms have been regarded as significant determinants in predicting the default risk (Grunert et al., 2005). Altman and Sabato (2007) reported that the length of business existence is one of the non-financial measures that have been used to predict the default. Indeed, there is an increasing interest among banks to use non-financial measures to make lending decisions. A study conducted by Grunert et al. (2005) involving 145 German banks, for example, reported that 70 banks use qualitative, in addition to the quantitative, information to assess credit risk management quality. In the context of their study, such quality measures as education level, experience, marketing analysis, management capability in handling the business have been used in assessing the quality management.

Li and Sheng (2018) suggested microfinance institutions that offer loans could use both a credit scoring model and a bank's loan officer's appraisals to produce a sound predictive model that measures the risk of potential borrowers. Information on potential borrowers' bank credit, education level, the status of being an existing client and the loan variable rate are factors that determine whether a borrower will default the loan payments. Similarly, work done by Balvanz, Yamanis, Mulawa, Mwikoko, Kajuna, Kilonzo, Kajula, Leatherman, \& Maman (2018) showed that the pattern of successful microfinancing payments by young men in Tanzania were influenced by "business experience, education, increasing number of children, community of residence, percentage of network members trained in business, and repayment success of peer leaders". Other factors include "leader influence, prior business experience, personal motivation, and planning facilitated repayment". The work suggested that enforcing accountability and rules, conducting trainings, and highlighting successful peers as role models could encourage repayments.

While the assessment of the quality management has been popular in the commercial banking industry, it is not uncommon to the microfinance industry as well. Norell's (2001) study, for example, indicated that microfinance providers have experienced massive cases of default loans. It reported that such cases are due to several reasons that are non-financial in nature. In explaining the influence of this non-financial information, the four (4) main reasons, which were outlined earlier, are therefore considered in this study. In particular, the reasons are due to the following: (a) 
lenders' seriousness and effectiveness in collecting loan payments that are due or outstanding are assessed by borrowers to be poor as a result of externally generated sources of microfinancing; (b) borrowers' resolution to utilise borrowed funds as a result of their exposure to unpredictable crises, such as illness or death of family members; (c) the opportunity for borrowers to use excess funds they derived from the bank to meet their personal ends without de-capitalising their businesses; and (d) borrowers intentionally delay or default loan repayments due to the practice of granting loans based on favouritism (hoping the bank to write-off their loans).

\section{Methodology}

Given that the focus of this study concerns the use of financial and other non-financial information in predicting the default risk of microfinance borrowers, this section reviews some extant literature. A variety of analytical techniques is being used for default prediction in previous research works. The techniques include statistical methods, artificial intelligence, contingent claims-based models and operational research methods, like linear programming and data envelopment analysis (Psillaki et al., 2010).

In this paper, we used logistic regression to investigate the predictive ability of financial and information on business operators' management and accounting skills as factors to predict the default risk of borrowers. In their research on the use of non-financial information in SMEs' risk management practices, Altman and Sabato (2007) had used logistic regression for default prediction. Logistic regression is particularly useful in determining the probability of firms to survive or fail when financial and non-financial factors are used as predictive indicators (Psillaki et al., 2010).

Data in this study was collected using questionnaires which were distributed to microfinance borrowers of a branch of a bank that provides micro financing facility. The questionnaires were distributed to target survey respondents which comprise of borrowers that operated their businesses within five $\mathrm{km}$ radius from the branch. This area was identified due to logistic reasons as we wanted to personally reach the respondents to secure a high response rate. We divided the respondents into with-in sample which represents $80 \%$ of the total respondents and were used for testing and hold-out sample which represents $20 \%$ of the total respondents, used for validation.

All respondents were required to tick or circle the numerical responses as opposed to written responses. This encouraged the respondents to participate in the survey as they perceived that the time taken to complete the questionnaires would be short and limited. The questionnaires were designed using three (3) types of scale in measuring the variables developed for this study. The first part of the survey consisted of "Yes" or "No" closed-ended questions. The close-ended questions were mainly used in this study to determine the respondents' business status and activities. The second and third part used 5-point and 10-point Likert scales, respectively. They measured the respondent's business management capabilities.

Data was collected through personally administered questionnaires. A sample size of 106 respondents was collected and analysed using logistic regression. They comprised of microfinance borrowers who were involved in retail businesses only. The respondents were divided into defaulting and non-defaulting borrowers in terms of their ability to meet the repayment terms of their respective loan agreements. In this regard, defaulting borrowers are referred to those who fail to honour their instalments when due. For instance, they make late payments for their loan instalments as stipulated in the loan agreements.

General respondents' profile consists of business entity, business ownership history, age of business, number or employees, gender, age, race, education background and business experience.

\subsection{The Variables}

The dependent variable is the repayment quality of the bank's borrowers coded as either default or non-default. The current practice of the bank in the study is to collect four (4) informational items related to the borrowers and these four (4) items will form the credit score after the evaluation done by the credit officer. The credit score determines the risk of potential borrowers and is denoted as A6 in Table 2. A potential customer that does not reach the threshold of the credit score set by the bank is considered as risky client.

The four (4) items that made up the credit score are personal references, financial analysis of the business operations, savings information of the borrowers and CCRIS record. The Central Credit Reference Information System or CCRIS essentially collects credit information of borrowers, summarises it into a credit report and supplies back the information to potential lenders. Financial institutions use the credit report to assess creditworthiness of potential clients. CCRIS was established by Bank Negara (The Central Bank of Malaysia).

References mean credit checking with the borrowers' suppliers and landlord (for rented business building). The bank makes cross checking with the borrowers' suppliers and landlord to determine the borrowers' ability to pay their 
obligations and meet their monthly commitment with their creditors. This is a way to determine the borrowers' repayment capability and financial strength in meeting their obligations.

Besides the credit score produced by the bank, we proposed to include another 42information collected through questionnaires from the borrowers. Grunert et al. (2005) in their research has proven the effectiveness of the combined use of financial and non-financial information that lead to a significant percentage of accuracy in the default prediction than a single use of financial or non-financial factors. The new information is listed in Table 2.

Table 2. Independent variables

\begin{tabular}{lll}
\hline a) & Code & Bank's Current Practice Items \\
\hline A6 & Credit Score \\
\hline b) & Code & New Information \\
\hline B2 & Age of business \\
C1 & Gender \\
C2 & Age of borrower \\
C4_ren & Primary \\
C4_men & Secondary \\
C51_5 & Experience range between 1-5 years \\
C56_10 & Experience range between 6-10 years \\
C510 & Experience more than 10 years \\
D1 & Availability of business plan \\
D2 & Availability of accounting records \\
D3 & Availability of marketing strategy \\
D4a & Engaging business consultant \\
D4b & Engaging business advisor \\
D5 & Product marketability \\
D6 & Utilisation of credit card for capital \\
D7 & Borrowing fund from family members, relatives and friends for \\
& business capital \\
D8 & Capital shortage \\
D9 & Cash flow sufficiency \\
D10 & Knowledge about competitors \\
D11 & Availability of credit purchases from suppliers \\
D12 & Cash purchases \\
D13 & Giving credit sales to customers \\
D14 & Cash sales \\
D15 & Succession plan \\
E3 & Leniency in borrowing terms \\
E5 & Approved loan amount meeting borrower's $\quad$ business \\
& requirement \\
F1a & Financial management \\
F1b & Cashflow management \\
F1c & Credit management \\
F2a & Stock control \\
F2b & Business planning \\
F2c & Knowledge and experience \\
F3a & Knowledge about competitors \\
F3b & Pricing of goods \\
F3c & Sales forecasting \\
F3d & Advertising \\
\hline & \\
\hline
\end{tabular}

We developed 3 models using a combination of variables in Table 2 to test the predictive ability of each model to classify loan defaulters from the non-defaulters. The 3 sets of models are as follows: 
a. Model 1: consists of bank's credit score only;

b. Model 2: consists of bank's credit score and information on business operators' management and accounting skills; and

c. Model 3: consists of information on business operators' management and accounting skills only.

The credit score is produced and used by the bank to assess credit worthiness of potential borrowers.

\subsection{Empirical Approach}

Out of 106 respondents participated in this study, 80\% responses were used in the testing sample and the remaining $20 \%$ consisting of 11 defaulted borrowers and 11 non-defaulted borrowers were used for validation. For each of the models described earlier, an analysis using logistic regression was performed on the with-in samples to find the significant variables. All significant variables were checked for multicollinearity. Further analysis using the significant variables was then performed on the hold-out sample. Validation was done to check for generalisation capability of the models. This approach has also been adopted by other similar studies (Altman \& Sabato, 2007). A model is considered a significant fit of the data if the model's chi-square statistics is less than 0.05 (Field, 2000). Two (2) measures of likelihood ratio are being reported. They are Cox-Snell $R^{2}$ and Negelkerke $R^{2}$. The value ranges between 0 and 1 . A value of 0 shows that the dependent variables have no predictive utility and 1 represents perfect prediction (Menard, 2001).

\section{Findings and Discussion}

Table 3 shows the descriptive analysis of selected independent variables. It shows that $48.1 \%$ of the total respondents defaulted with $43.1 \%$ of them being males. On their highest education level, $48.1 \%$ of respondents indicated that they received primary education and $51.9 \%$ received secondary education. Out of those who received primary education, $60.8 \%$ are defaulters and $39.2 \%$ are non-defaulters. For respondents who received secondary education, 20 of them are defaulters and 35 are non-defaulters. When asked about their experience in business, which is categorised into three (3) groups, 60 respondents have 1-5 years' business experience, 24 respondents have 6-10 years' business experience and the remaining 22 respondents have more than 10 years' business experience. For respondents with experience ranging between $1-5$ years, $51.7 \%$ of the total respondents defaulted. For those with experience of more than 10 years, only $27.2 \%$ are defaulters while $58.3 \%$ of respondents with experience ranging between 6-10 years defaulted.

Table 3. Frequency summary

\begin{tabular}{|c|c|c|c|c|c|}
\hline No & Variables & Default & Non-default & $\begin{array}{l}\text { Sub } \\
\text { Total }\end{array}$ & Total \\
\hline 1. & $\begin{array}{l}\text { Firms } \\
\text { (default/non-default) }\end{array}$ & 51 & 55 & - & 106 \\
\hline \multirow[t]{3}{*}{2.} & Gender & & & & \\
\hline & Male & 22 & 29 & 51 & \\
\hline & Female & 29 & 26 & 55 & 106 \\
\hline \multirow[t]{3}{*}{3.} & Education level & & & & \\
\hline & Primary & 31 & 20 & 51 & \\
\hline & Secondary & 20 & 35 & 55 & 106 \\
\hline \multirow[t]{4}{*}{4.} & Experience in business & & & & \\
\hline & $1-5$ years & 31 & 29 & 60 & \\
\hline & 6-10 years & 14 & 10 & 24 & \\
\hline & $>10$ years & 6 & 16 & 22 & 106 \\
\hline
\end{tabular}

The classifying accuracy for each model is shown in Table 4. Model 1 consists of credit score produced by the bank's credit officer and is the current practice used by the bank. Model 2 consists of the credit score and the extra information gathered in the study while model 3 was made of the extra information only without the credit score. Model 3 has the highest accuracy rate at $94.1 \%$ in classifying non-defaulted firms as non-defaulting but together with model 1 has the lowest accuracy rate of $65 \%$ in classifying defaulted firms as defaulting. The ability to predict defaulting firms is of more informational value than the ability of predicting non-defaulting firms. Model 2 , which contains the credit score and the extra information, performed the best among the three (3) models with overall classification accuracy of $86.9 \%$. 
Table 4. The classification rate

\begin{tabular}{lccc}
\hline & $\begin{array}{l}\text { Model 1 (credit } \\
\text { score only) }\end{array}$ & $\begin{array}{l}\text { Model 2 (credit } \\
\text { score and extra } \\
\text { information) }\end{array}$ & $\begin{array}{l}\text { Model 3 (extra } \\
\text { information } \\
\text { only) }\end{array}$ \\
\hline $\begin{array}{l}\text { Percentage correct } \\
\text { in classifying }\end{array}$ & 75 & 86.4 & 94.1 \\
$\begin{array}{l}\text { non-defaulted firms } \\
\text { Percentage correct } \\
\text { in classifying }\end{array}$ & 65 & 87.5 & 65 \\
$\begin{array}{l}\text { defaulted firms } \\
\text { Overall percentage }\end{array}$ & 70.2 & 86.9 & 75 \\
\hline
\end{tabular}

Table 5 shows the values of $-2 \mathrm{LL}$, Cox \& Snell $\mathrm{R}^{2}$ and Nagalkerke $\mathrm{R}^{2}$ for all models. A lower value of $-2 \mathrm{LL}$ indicates a better model. On the other hand, for $\operatorname{Cox} \&$ Snell $\mathrm{R}^{2}$, Nagalkerke $\mathrm{R}^{2}$, the highest value shows the best model. The value of $-2 \mathrm{LL}$ of the model 2 is the lowest and the values of Cox $\&$ Snell $\mathrm{R}^{2}$ and Nagalkerke $\mathrm{R}^{2}$ are the highest for the same model 2. This means that model 2 shows the highest association between the independent and the dependent variables.

Table 5. -2LL, Cox \& Snell R2, Nagalkerke R2

\begin{tabular}{cccc}
\hline Model & $\begin{array}{c}-2 \text { Log likelihood } \\
(-2 \mathrm{LL})\end{array}$ & $\begin{array}{c}\text { Cox \& Snell } \\
\text { R2 }\end{array}$ & $\begin{array}{c}\text { Nagalkerke } \\
\text { R2 }\end{array}$ \\
\hline 1 & $99.934 \mathrm{a}$ & .177 & .236 \\
2 & $60.972 \mathrm{a}$ & .482 & .643 \\
3 & $92.372 \mathrm{a}$ & .248 & .330 \\
\hline
\end{tabular}

The results are the three (3) models were validated using the hold-out sample. Model 2 outperformed the other two (2) models in both the with-in and with-out samples with the overall classification accuracy rate for the hold-out sample to be $90.9 \%$ as shown in Table 6.

Table 6. Overall classification rate

\begin{tabular}{ccc}
\hline Mode & \multicolumn{2}{c}{ Overall Classification Rate } \\
\cline { 2 - 3 } 1 & Hold-in $(\%)$ & Hold-out $(\%)$ \\
\hline 1 & 70.0 & 86.0 \\
2 & 86.9 & 90.9 \\
3 & 75.0 & 81.8 \\
\hline
\end{tabular}

The significant variables as shown in Table 7 of model 2 at 5\% significant level are A6 (the credit score), C56_10 (experience in business range between 6-10 years), D11 (availability of credit purchases), F1a (financial management capability) and F3c (sales forecasting). Besides the credit score, the rest of the significant variables are new information collected for this study. It shows that good credit rating, business experience, business financial and forecasting capability are factors associated whether SMEs will default or not in their payments.

Table 7. Significant Variables - Model 2

\begin{tabular}{llcccccc}
\hline & & B & S.E. & Wald & Df & Sig. & $\operatorname{Exp(B)}$ \\
\hline Step 1a & A6 & -20.079 & 5.361 & 14.030 & 1 & .000 & .000 \\
& C56_10 & 3.640 & 1.102 & 10.921 & 1 & .001 & 38.103 \\
& D11 & 2.046 & .830 & 6.079 & 1 & .014 & 7.739 \\
& F1a & .649 & .228 & 8.064 & 1 & .005 & 1.913 \\
& F3c & -.627 & .204 & 9.412 & 1 & .002 & .534 \\
& Constant & 7.774 & 3.501 & 4.931 & 1 & .026 & $2.378 \mathrm{E} 3$ \\
\hline
\end{tabular}




\section{Conclusion, Limitations and Recommendations}

In this paper, we used logistic regression to investigate the predictive ability of newly introduced variables as predictors of default. The data were gathered from a bank's microfinance borrowers who were involved in retail businesses and operating their businesses within five $\mathrm{km}$ radius from the location of the branch bank. We compared three (3) models which consist of a combination of various old and new information to predict default in loan repayments among the microfinance borrowers.

The findings suggest that the combination of credit score used currently by the bank and the new information (information on business operators' management and accounting skills) produced by this paper increases the bank's ability to predict default. This paper has provided empirical evidence on the importance of the extra information (or indicators) to determine credit risk for assessing microcredit application at the bank. The findings of the paper are of importance to the banking industry especially in the microfinance segment in terms of maintaining and improving the credit assessment to predict default. By using the right variables in the credit assessment for the loan applications, it will enable banks to identify and predict the future repayment capability of the borrowers so as to minimise default incidents. Borrowers with satisfactory repayment records should enable banks to achieve their desired financial performance as they can minimise the associated risks and financing costs. This is based on an argument that maintaining bad paymaster or default portfolio requires the banks to engage some collection personnel, which ultimately increases the operational costs.

Our analysis shows that a lack of good credit rating, availability of credit purchases, business experience, good business financial planning and forecasting capability are among the factors associated with default. Such factors imply the importance of determining financial and non-financial indicators to assess credit risk associated with microfinance's loan applications at the studied bank's branch. This calls for the banking industry (especially microfinance providers) to maintain and improve the credit assessment to predict default. By using the right variables in the credit assessment for the loan applications, a bank is better able to identify and predict the future repayment capability of its borrowers with the expectation that default occurrences would be minimised, if impossible to be abolished. In the perspective of a bank, good borrowers with satisfactory repayment records should ensure the achievement of desired profits as they incur little (or insignificant amount of) costs. Meanwhile, maintaining bad paymaster or default portfolio requires a bank to engage collection personnel to do the collections from the default borrowers which eventually increase its operational costs.

Despite the interesting findings offered by this study, however, it is important to highlight some limitations. The first limitation of the study concerns the availability of articles and journals written specifically about credit assessment on microfinancing of Malaysian banks specifically in the retail industry. Many articles and journals that are used in this study have merely highlighted the importance of financial and non-financial information in assessing credit risk and default risk focusing on industries other than the retail industry. The second limitation concerns transparency and availability of certain information which may not be possible to obtain or is appropriately revealed in view of the bank's internal information governed under Banking and Financial Institutions Act 1989 (BAFIA). The third limitation concerns the restricted scope of data to only borrowers that operate their businesses within five (5) $\mathrm{km}$ radius of the location.

Thus, we recommend that future research should include samples of microfinance borrowers from other industries. Besides, it should include the mode of monthly loan repayment as other non-financial information in predicting default risk given that the mode of monthly repayment such as through cash deposit, checks or standing instructions may affect the repayment pattern of the borrowers. Future research may consider investigating the distance between the borrowers' business area and the nearest branch which may affect the repayment trend and may cause the loan to be defaulted. Lastly, future research should identify other variables, such as the attitude of borrowers towards paying on time, which may be significant in predicting the default risk of loans.

\section{References}

Abdou, H. A., \& Pointon, J. (2011). Credit scoring, statistical techniques and evaluation criteria: A review of the literature. Intelligent Systems in Accounting, Finance and Management, 18(2-3), 59-88.

Addae-Korankye, A. (2014). Causes and control of loan default/delinquency in microfinance institutions in Ghana. American International Journal of Contemporary Research, 4(12), 36-45.

Ahmad, A. R., Azhar, Z., \& Wan-Abu-Bakar, W. A. (2010). Cash-flows ratios as predictors of corporate failure. In 2010 IEEE Symposium on Industrial Electronics and Applications (ISIEA) (pp. 255-258). IEEE. 
Aidoo, M., \& Mensah, F. S. (2018). The causes of default loans risk in microfinance institutions in Ghana: Case study of some selected microfinance institutions in Kumasi and Accra. Global Journal of Management and Business Research, 18(2), 23-37.

Altman, E. I., \& Sabato, G. (2007). Modelling credit risk for SMEs: Evidence from the US market. Abacus, 43(3), 332-357.

Altman, E. I., Sabato, G., \& Wilson, N. (2017). Assessing SME Default Risk in the UK. Working paper, Wiserfunding, London.

Balvanz, P., Yamanis, T. J., Mulawa, M. I., Mwikoko, G., Kajuna, D., Kilonzo, M. N., ... Maman, S. (2018). Microfinance and health interventions: Factors influencing loan repayment success with young men in Dar es Salaam, Tanzania. Global Public Health, 14(2), 254-270.

Battilana, J., \& Dorado, S. (2010). Building sustainable hybrid organizations: The case of commercial microfinance organizations. Academy of Management Journal, 53(6), 1419-1440.

Bottazzi, L., Da Rin, M., \& Hellmann, T. (2009). What is the role of legal systems in financial intermediation? Theory and evidence. Journal of Financial Intermediation, 18(4), 559-598.

Cornée, S. (2017). The relevance of soft information for predicting small business credit default: Evidence from a social bank. Journal of Small Business Management, 57(3), 699-719.

Dimitras, A., Papadakis, S., \& Garefalakis, A. (2017). Evaluation of empirical attributes for credit risk forecasting from numerical data. Investment Management and Financial Innovations, 14(1), 9-18.

Doumpos, M., Lemonakis, C., Niklis, D., \& Zopounidis, C. (2019). Introduction to Credit Risk Modeling and Assessment. In Analytical Techniques in the Assessment of Credit Risk (pp. 1-21). Springer, Cham.

Field, A. (2000). Discovering Statistics Using SPSS for Windows. Sage Publications Ltd.

Günther, T., \& Grüning, M. (2000). Einsatz von insolvenzprognoseverfahren "bei der kreditwurdigkeitspr" ufung im firmenkundenbereich. Die Betriebswirtschaft, 60(1), 39-59.

Grunert, J., Norden, L., \& Weber, M. (2005). The role of non-financial factors in internal credit ratings. Journal of Banking \& Finance, 29(2), 509-531.

Jayasekera, R. (2018). Prediction of company failure: Past, present and promising directions for the future. International Review of Financial Analysis, 55, 196-208.

Krahnen, J. P., \& Weber, M. (2001). Generally accepted rating principles: A primer. Journal of Banking \& Finance, 25(1), 3-23.

Li, J., \& Sheng, Z. (2018). Measuring and managing credit risk for Chinese microfinance institutions. International Journal of Economics and Finance, 10(7), 56-63.

Menard, S. (2001). Applied logistic regression analysis (2nd ed., Vol. 106). Thousand Oaks, CA: Sage.

Norell, D. (2001). How to reduce arrears in microfinance institutions. Journal of Microfinance/ESR Review, 3(1), 115-130.

Psillaki, M., Tsolas, I. E., \& Margaritis, D. (2010). Evaluation of credit risk based on firm performance. European Journal of Operational Research, 201(3), 873-881.

Sama, L. M., \& Casselman, R. M. (2013). Profiting from poverty: Ethics of microfinance in BOP, South Asian Journal of Global Business Research, 2(1), 82-103.

Schreiner, M. (2000). Credit scoring for microfinance: Can it work?. Journal of Microfinance/ESR Review, 2(2), 105-118.

Siti-Nabiha, A. K., Azhar, Z., Isa, S. M., \& Siti-Nazariah, A. Z. (2018a). Measuring social performance: reconciling the tension between commercial and social logics. International Journal of Social Economics, 45(1), 205-222.

Siti-Nabiha, A. K., Azhar, Z., \& Ali-Mokhtar, M. A. (2018b). Management control for microfinance: An examination of the belief system of a Malaysian microfinance provider. Asian Academy of Management Journal of Accounting \& Finance, 14(1), 185-208.

Siti-Nazariah, A. Z., Siti-Nabiha, A. K., \& Azhar, Z. (2016). Managing social and economic performance in social enterprise. Journal of Business Management and Accounting, 6(1), 47-74. 
Treacy, W. F., \& Carey, M. (2000). Credit risk rating systems at large US banks. Journal of Banking \& Finance, 24(1), 167-201.

Zavgren, C. V. (1985). Assessing the vulnerability to failure of American industrial firms: A logistic analysis. Journal of Business Finance \& Accounting, 12(1), 19-45.

\section{Note}

Note 1 . In the context of this study, retail consists of business that involved in sales of goods or merchandise from a very fixed location, such as a departmental store, boutique or kiosk, or by mail whether in small or individual lots for direct consumption by the purchasers. 